University of Wollongong

Research Online

Faculty of Commerce - Papers (Archive) Faculty of Business and Law

March 2006

\title{
A Cross-Country Analysis of Export Prices in OECD Countries
}

Abbas Valadkhani

University of Wollongong, abbas@uow.edu.au

A. P. Layton

University of Southern Queensland

Follow this and additional works at: https://ro.uow.edu.au/commpapers

Part of the Business Commons, and the Social and Behavioral Sciences Commons

\section{Recommended Citation}

Valadkhani, Abbas and Layton, A. P.: A Cross-Country Analysis of Export Prices in OECD Countries 2006. https://ro.uow.edu.au/commpapers/383

Research Online is the open access institutional repository for the University of Wollongong. For further information contact the UOW Library: research-pubs@uow.edu.au 


\title{
A Cross-Country Analysis of Export Prices in OECD Countries
}

\begin{abstract}
As is the case with most small open economies, changes in Australia's export prices are an important source of national macroeconomic disturbance largely out of its control given its choice of export bundle. This paper distinguishes the extent to which export price variation consists of global versus countryspecific changes for the set of 14 OECD countries investigated. We find that sharp changes in global export prices are evidently becoming more important for many of the countries in the OECD sample over the last 25 years as compared with the previous 25 year period. The paper also finds that, by a number of different measures, whilst Australia's export price growth has apparently become more highly associated with World export prices in recent years, it nonetheless continues to have one of the more volatile set of export prices among OECD countries.
\end{abstract}

\section{Keywords}

Australia, Export prices, OECD countries

Disciplines

Business | Social and Behavioral Sciences

\section{Publication Details}

This article was originally published as Valadkhani, A and Layton, A, A Cross-Country Analysis of Export Prices in OECD Countries, Economic Papers, 25(4), 2006, 331-346. 


\title{
A CROSS-COUNTRY ANALYSIS OF EXPORT PRICES IN OECD COUNTRIES
}

\author{
ALLAN P. LAYTON*
}

and

ABBAS VALADKHANI**

\footnotetext{
* Faculty of Business, The University of Southern Queensland, Toowoomba Qld 4350.

** the corresponding author, School of Economics and Information Systems, University of Wollongong, NSW 2522, Email: abbas@uow.edu.au
} 


\section{A CROSS-COUNTRY ANALYSIS OF EXPORT PRICES IN OECD COUNTRIES}

As is the case with most small open economies, changes in Australia's export prices are an important source of national macroeconomic disturbance largely out of its control given its choice of export bundle. This paper distinguishes the extent to which export price variation consists of global versus country-specific changes for the set of 14 OECD countries investigated. We find that sharp changes in global export prices are evidently becoming more important for many of the countries in the OECD sample over the last 25 years as compared with the previous 25 year period. The paper also finds that, by a number of different measures, whilst Australia's export price growth has apparently become more highly associated with World export prices in recent years, it nonetheless continues to have one of the more volatile set of export prices among OECD countries.

\section{Introduction}

As is the case with most small open economies, fluctuation in Australia's export prices is an important source of national macroeconomic disturbance largely out of its control given its choice of export bundle. The risk associated with this price volatility may be viewed as derived from factors specific to that particular country as well as from influences more global in nature. If one views a country's export bundle as a portfolio of assets in which it has chosen to invest its scarce resources, the wellknown Capital Asset Pricing Model (CAPM) of portfolio theory may provide a loose, but useful, framework for distinguishing the extent to which its overall export price volatility consists of global versus country-specific risk. In addition, an estimate of 
the extent of the sensitivity of the country's export prices to system-wide global fluctuations (its $\beta$ ) may be obtained.

Whilst having general application, motivation for the paper stems from recent economic debate in Australia regarding whether the nation's export bundle consisting even today to a large extent of primary products (around 50\%) - is too narrowly based. An open economy by most criteria, its exports account for about 22 per cent of GDP in 2002 and, in keeping with any open economy devoting a significant proportion of its resources to export production, prices received for such exports are an important determinant of national income and social welfare.

As just mentioned, volatility in Australia's export prices is an important source of national macroeconomic disturbance. There are a large number of empirical analyses which have examined the impact of the terms of trade on Australia's economy (e.g. McTaggart and Rogers, 1990, Harvie and Tran, 1993, 1994, Gruen and Wilkinson, 1994, Fisher, 1996, Gruen, and Kortian, 1996). For instance, Hoque (1995) examines the relationship between the terms of trade and current account outcomes in Australia. Based on his empirical findings, he asserts that the terms of trade impacted on Australia's current account balance during the fixed exchange rate regime but not during the flexible exchange rate era.

In a more comprehensive study, Gruen and Dwyer (1996) examine the interaction among the terms of trade, the real exchange rate and inflation and, inter alia, they find that an increase in the terms of trade can be inflationary if the corresponding rise in the real exchange rate is less than $1 / 3-1 / 2$ of the rise in the terms of trade. Kent (1997) and Cashin and McDermott (2002) in their cross-country analyses argue that, depending on the degree of persistence, the current account responds differently to the shocks associated with the countries' terms of trade. It is 
also found that terms of trade shocks account for a considerable proportion of the volatility of current account balances in Australia and New Zealand (Cashin and McDermott, 2002).

Whilst its export bundle consists to a large extent of primary products, Australia's imports are almost entirely manufactures with possibly more stable prices, supporting the view that changes in Australia's terms of trade "are largely the result of export prices changing by more than import prices" (McTaggart and Rogers, 1990, p.38). Australia's export and import bundles are quite different and, given the smallcountry price-taking assumption, this implies the purchasing power of its exports (in terms of imports) can be subject to considerable fluctuations. For this reason, therefore, it is argued by some that Australian authorities should institute policies (tax incentives etc) to encourage an expansion of the nation's export base into more highly value-added manufactures. This, it is suggested, would induce more stability into the country's terms of trade, thereby reducing such exogenous disturbances.

Of course, whatever justification there may be for such a course, it is clearly predicated, in part, on the assumption that Australia's export prices are in fact "too" volatile in some sense. In this regard, the obvious, and most common, approach to measuring a country's export price volatility is to compare it internationally with the usual statistical measures of volatility being standard deviation or coefficient of variation. Thus a country with, say, a larger export prices standard deviation may be interpreted as being exposed to greater export price risk.

However, such measures are limited in the information they convey in that they only measure overall volatility or risk. To illustrate, two countries may have similar overall risk but the nature of their risk exposure may be very different. For instance, one country's price variation may be largely due to global factors common 
to many countries while the other's prices may fluctuate because of factors specific to it or just a few countries. In this situation, assuming reduced volatility was considered desirable by policymakers, the second country may well have more to be gained from export diversification than the first (assuming it could, through some appropriate means, pursue such diversification).

The analogous situation in an investment context would be an investor (country) holding a highly diversified asset portfolio (export bundle) with little remaining diversifiable risk as opposed to another investor holding a different, nondiversified portfolio with considerable scope for risk reduction through appropriate diversification.

The idea of the application of portfolio theory to the issue of export price volatility is developed in the next section. The empirical results of the application of the approach to a number of countries are presented in Section 3 and conclusions follow in the last section.

\section{Conceptual and Measurement Issues}

Conceptually a country's export prices are measured in index number form in terms of some selected base year. A given year's index value measures the level of the average price of an export bundle in that year as a proportion of the average price of the base year bundle. One source of such international price index data is International Financial Statistics (http://ifs.apdi.net/imf/logon.aspx) which publishes export unit value series (having the interpretation of implicit price deflators) for a wide selection of countries all expressed in US dollars. The most recent base used in IFS for each country is 1995 and is the base used in this study. The OECD countries selected for inclusion in the comparison are Australia, Canada, Finland, 
Germany, Ireland, Italy, Japan, Netherlands, Norway, New Zealand, Spain, Sweden, the UK and the US. According to the online IFS database, consistent OECD country data for the period under investigation are available only for these 14 countries.

As mentioned in the introduction, common statistical measures of volatility are standard deviation (SD) and coefficient of variation (CV). Of these, $\mathrm{CV}$ (defined as SD divided by the mean of the data) is preferred as a relative volatility measure when measurements being compared have different means. Of course, for these measures to have meaningful interpretation, the time series data to which they relate should be stationary. As the data in question here are price indices with evident trend this stationarity assumption is unlikely to hold. For this reason the basic data under investigation are converted to natural logs and first differenced so that each series is essentially transformed into growth rates. Such series are likely to be stationary and so the ensuing analysis will concern volatility in export price growth rates.

Figure 1 therefore shows the plots of the annual growth rate of export prices for Australia, the World and a number of OECD countries for the 1948-2002 period. An informal inspection of these graphs supports the fact that Australia's export prices are more volatile than those of many other countries, including the "World" as a whole, particularly until the early 1990s. Furthermore, a similar conclusion emerges using SD or CV as volatility measures. This will be further discussed in detail below.

\section{[Figure 1 about here]}

While volatility measures such as SD and CV are certainly useful, as noted in the introduction, they necessarily only measure overall variation in a country's export price growth. However this overall variation will, broadly speaking, not only be the result of country-specific factors, but also of global influences impacting to a greater or lesser extent on different countries. Differentiating these two components would 
therefore provide additional information about a country's export price volatility beyond that conveyed by SD and CV. Furthermore, some basic concepts in the field of portfolio theory may be used to provide a useful basis for such a differentiation.

The theory underlying the CAPM was originally formulated by Markowitz (1959) and further developed in the following decade by Sharpe (1964), Lintner (1965) and Mossin (1966). The CAPM specifies that the expected return of an asset is equal to the riskless return plus a measure of the assets non-diversiable risk ("beta") times the market-wide risk premium (excess expected return of the market portfolio over the riskless return) or more formally:

$$
E\left(r_{i}\right)=r_{f}+\beta_{i m}\left[E\left(r_{m}\right)-r_{f}\right]+\varepsilon_{t}
$$

where: $E\left(r_{i}\right)$ is the expected rate of return on an asset; the intercept, $r_{f}$, denotes the risk-free interest rate; $\beta_{i m}$ represents the sensitivity of the $\mathrm{i}^{\text {th }}$ asset returns to market returns, or also $\beta_{i m}=\operatorname{Cov}\left(r_{i}, r_{m}\right) / \operatorname{Var}\left(r_{m}\right)$; and $E\left(r_{m}\right)-r_{f}$ is the excess - compared with the risk free rate - return from holding the overall market portfolio. The model captures the basic finance relationship between risk and expected return. According to this theory, a more risky asset (relative to the market portfolio) will have a relatively higher expected rate of return to compensate risk averse investors for the greater risk.

More specifically, the CAPM is a logical extension of mean-variance theory and asserts that a financial asset's equilibrium rate of return is related to the return available on the market portfolio adjusted to account for the extent to which variation in the asset's return is correlated with variation in that of the market portfolio (determined according to whether $\beta$ is $<,=,>1$ ). Conceptually the market portfolio is a highly diversified portfolio of assets (for example, all the listed companies in the Australian All Ordinaries Index) and therefore fluctuations in its return may be regarded as representing the result of the impact of overall economy-wide factors 
affecting the entire asset market. Thus the risk associated with holding such a highly diversified portfolio is viewed as non-diversifiable risk and is known as market risk.

Variation in the return on a particular asset may be thought of as being in part the result of the same economy-wide factors as are affecting the market portfolio as well as asset-specific factors (for example, good or bad management practices in the case of a company stock). To distinguish the extent of its dependence on the two types of factors the asset's return may be regressed on the market portfolio's return. The variation in the asset's return which can be explained by variation in the market portfolio is known as the asset's systematic risk and the residual variation is the asset's unsystematic or asset-specific risk. The latter can be diversified away by combining the asset with others in a portfolio while the former cannot.

The slope coefficient in this regression is referred to as the asset's "Beta Coefficient" and is very important in portfolio investment decision making. For example, if the asset in question has a Beta greater than one this implies its return is more sensitive to systematic economy-wide risk than is the market portfolio. In equilibrium, rational risk averse investors - to compensate them for the additional asset-specific risk - will therefore require a higher rate of return on such an asset than the return on the market portfolio.

In the current context then we can think of a country's export price variation as consisting of a component due to overall global macroeconomic factors - this could be called, say, global risk - and a component due to more localised factors affecting that particular country - called, say, country-specific risk. Furthermore, it seems reasonable to argue that, in assessing a country's exposure to export price volatility risk, interest should focus not only on overall export price variation but also on 
distinguishing its country-specific risk component from its global risk component and in determining its sensitivity to such global risk (its Beta).

To illustrate, country A may have greater overall export price growth volatility - as measured by SD or CV - than country B, but the volatility of A may derive mainly from global risk while that of B principally from country-specific risk. This means the fortunes of the first are closely tied to internationally common macroeconomic factors whilst the second's are determined by some different set of influences perhaps quite unique to it. Thus, should B wish to reduce its export volatility, it may actually have more to be gained from diversification than A. Alternatively two countries may have similar high proportions of global risk but one may have a much higher Beta. This means that, while the export price growth volatility of both is well explained by common global macroeconomic factors, the export prices of the country with the higher Beta are much more sensitive to such worldwide factors. Knowledge of distinctions such as these should prove beneficial from the policy debate point-of-view.

To enable the factoring out of global from country-specific risk each country's export price growth series is regressed against the export price growth rate of some appropriate proxy for the global export portfolio. For current purposes the IFS 'World Export Price Index' is used as the basis of this latter growth rate series. The use of growth rates as the regression variable also helps to ensure the validity of the stationarity assumption required in classical regression. Some aspects of these results are discussed in the next section. ${ }^{1}$

\footnotetext{
${ }^{1}$ It should perhaps be explicitly noted again here that the CAPM is being used as a loose, though hopefully useful framework within which to more critically investigate a country's export price volatility. Like all analogies, the current analogy of a country's export portfolio to that of an individual investor's portfolio should not be pushed too far.
} 


\section{Empirical Results}

Table 1 presents the estimated $\beta$ (the slope of the regression) together with other relevant econometric results for all the 14 OECD countries using all the available data. The sampling frequency chosen was annual and the estimation period for various countries was as follows: Canada, Finland, Ireland, Italy, Norway and New Zealand (1949-2002); Australia (1949-2001); Germany and Sweden (1951-2002), Japan (1953-2002); Netherlands, the UK and the US (1950-2002), and Spain (1955-2002).

As can be seen, all estimated $\beta$ s are statistically significantly different from zero at the .01 level of significance, however, given the long period covered by the sample, it is important to investigate the issue of the stability of the estimated $\beta$ coefficients through time. In order to test this possibility we have presented recursive $\beta$ estimates for all these 14 countries in Figure 2. A cursory look at Figure 2 clearly reveals that the slope coefficient was subject to a considerable structural break around 1975 - just after the first oil price shock occurred - in all countries examined in this study. Based on this finding, we have split the entire sample period into two subsamples, viz. the pre-1976 period (up to and including 1975) and the post-1975 period (1976-2002). This split also yields two sub-samples of roughly the same duration for the countries under study.

\section{[Table 1 about here]}

\section{[Figure 2 about here]}

The estimated $\beta$ coefficient, $t$-ratio, the coefficient of determination $\left(R^{2}\right)$ and the other relevant econometric results for each such regression are shown in Table 2 for the two separate sample periods. The estimated $\beta$ coefficients are all significantly different from zero and positive, and have values which seem reasonable. The usual D/W tests are all acceptable, suggesting the absence of significant serial correlation. 
In order to facilitate cross-country comparisons, we have assigned a rank to each country in Table 3 according to magnitudes of the standard deviation (SD), the coefficient of variation $(\mathrm{CV}), \beta, R^{2}$, and the standard error of the estimated regression (or $\hat{\sigma}$ ). A higher rank indicates a higher relative value of the corresponding statistic for the country in question in comparison to other countries in the set.

Let us first consider overall volatility. Of the two measures, SD and CV, we prefer CV since it adjusts a country's "raw" export price volatility (as measured by, say, SD) for its average export price growth. Thus, a country may be experiencing higher short term export price volatility than another but may also be experiencing faster medium term export price growth. The higher medium term price growth may in keeping with portfolio theory - be regarded as compensating for the higher short term volatility. The CV volatility measure therefore captures, at least to some extent, this risk/return tradeoff. The SD and CV data can be found in Table 3.

In Australia's case, not only did its CV increase in the post-1975 period (from $683 \%$ to $900 \%$ ) but its international rank also increased from the $5^{\text {th }}$ highest to the $2^{\text {nd }}$ highest (only Finland had a higher CV). In both absolute and relative terms then, the volatility of Australia's export prices has increased markedly between the two subperiods. These results therefore seem to lend some prima facie support to those who argue Australia's export prices are relatively "too" volatile.

[Table 2 about here]

[Table 3 about here]

Australia's situation can also be contrasted with a number of other countries. For example, NZ had a similar CV to Australia in the pre-1976 period but it reduced considerably in both absolute and relative terms in the post-1975 sub-sample. On the other hand Canada's export price volatility - in both absolute and relative terms - 
changed little across the two sub-periods. Finally, the US had the least volatile export prices of any country using $\mathrm{CV}$ as the overall volatility measure.

Of course, all of this relates to overall volatility. It is also of interest to determine to what extent a country's overall volatility is the result of global fluctuations in export prices as opposed to variation which is the result of more country-specific factors. Consider Table 2. Interestingly, $R^{2}$ for nine of the 14 countries increased between the two sub-periods. This can be interpreted as indicating that, for these countries, variation in their export prices more closely followed that of World export prices in the post-1975 period, which may be further interpreted as implying that global factors became relatively more important for those countries. Those countries for which this was not the case were Canada, the US, Japan, Germany and Norway.

In the case of Australia and NZ, $R^{2}$ increased from $27 \%$ and $11 \%$ respectively to $56 \%$ and $65 \%$ respectively, implying that, for these countries, their export price variation followed World export price variation much more closely in the second period. This is one explicit measure of the extent to which diversification of each country's export base has apparently occurred over the total period of the analysis.

Also of interest in Table 2 is what occurred to each country's Beta over the two sub-periods. As noted above, a country's $\beta$ may be interpreted as indicating its sensitivity to common global fluctuations. A larger $\beta$ implies a country is relatively more sensitive to systematic global factors. Parenthetically, it should be noted that this does not necessarily imply the country also has a high $R^{2}$. For instance, it is quite possible for country-specific influences to be relatively more important than global factors (a low $R^{2}$ ) in accounting for a country's total export price volatility but, 
nonetheless, the country's export prices may respond quite significantly (a high $\beta$ ) to changes in global trends when they do occur.

Take the US, for example. Not only did its $R^{2}$ reduce from $90 \%$ to $66 \%$ over the two periods, but its Beta also reduced from .69 to .33. In other words, for the US, not only does World export price variation account for substantially less of its overall price volatility in the post-1975 period, but, when variation in World prices does occur, the average response in US export variation is less than half what it was in the pre-1976 period! Considering the four majors, both Japan and the US in the second period are estimated to be relatively insensitive or inelastic to global influences whereas Germany and the UK are apparently relatively more responsive.

Finally, for most countries, the estimated Beta increased between the two periods suggesting that, for those countries, their export price movements became more sensitive to fluctuations in World prices. For example, in the case of Australia and NZ, not only has each country's $R^{2}$ increased but each country's estimated Beta has also increased - both estimates were close to one in the second sub-period. This again suggests a greater association of each country's export prices with World export prices in the post-1975 period and is suggestive of greater export diversification in the latter period.

We have also tested the null of $\beta=1$ for each country and different subperiods, and the Wald test results are presented in Table 4. Based on these results the null cannot be rejected for the majority of the countries under investigation - including Australia - in the post-1975 period. This means that, for Australia for example, not only has global risk evidently become more important (increasing $\mathrm{R}^{2}$ ) in recent years, but also that the growth of Australia's export prices can be expected to respond approximately proportionately to global trends when they do occur. 


\section{[Table 4 about here]}

One final statistic of interest in Table 2 is $\hat{\sigma}$, the standard error of regression for each country. This is a measure of a country's residual export price volatility which cannot be explained by World Export prices. We interpret this statistic as an indication of the extent to which the variation in a country's export price growth arises from country-specific factors rather than global factors. It should be clarified, of course, that $R^{2}$ (or, more precisely, $1-R^{2}$ ) potentially provides very similar information. Indeed, if a country's overall price volatility remained unchanged across both periods, then an increase in $R^{2}$ (suggesting a greater association with global factors) would necessarily be associated with a reduction in $\hat{\sigma}$. However, if overall volatility in a country's export prices increased across the two periods, it is quite possible for both $R^{2}$ and $\hat{\sigma}$ to increase. This would indicate that a greater proportion of the country's higher volatility could be accounted for by global factors but, nonetheless, the country is still experiencing greater country-specific volatility in the second period compared with the first.

As can be seen from Table 2 nine countries show either a reduction or an immaterially small increase in country-specific volatility (as measured by $\hat{\sigma}$ ) in the second period. Those which evidence an increase are Canada, Finland, Germany, Japan and Norway. Again, Australia and NZ both exhibit a reduction in residual country-specific volatility. In fact, interestingly, both had very similar values for $\hat{\sigma}$ in both sub-periods. This again is suggestive of increased export diversification in both countries across the two periods.

As far as the US is concerned, it may be seen that, although its $R^{2}$ reduced across the two periods (quite substantially), since the overall volatility of US export prices (as measured by SD and CV) also reduced across the two periods, the $\hat{\sigma}$ for the 
US remained virtually unchanged, and remained the smallest of any country in both sub-periods. In other words the US has the least estimated country-specific variation, in both sub-periods. Comparing the four major industrialised nations, the estimated $\hat{\sigma} \mathrm{s}$ in the post-1975 period indicate that both Japan and Germany are estimated to have relatively more country-specific variation in their export prices whereas both the United Kingdom and the United States have relatively less.

Finally, interpreting $\hat{\sigma}$ as representing non-systematic, diversifiable risk which a country could avoid by endeavouring to diversify its export bundle, then, in Australia's case, such diversification would seem to be in evidence across the two sub-samples. However, according to Tables 2 and 3, whilst Australia's $\hat{\sigma}$ decreased from 0.117 in the pre-1976 period to 0.057 in the post-1975 period, this only reduced its $\hat{\sigma}$ rank from 11 to nine amongst the countries under investigation. Thus, Australia's country-specific risk remains the sixth highest amongst the other reported OECD countries.

As can be seen from Tables 2 and $3, \hat{\sigma}$ for the US, the UK and Canada are lower than that of Australia (considerably so in the case of the UK and US). Reducing $\hat{\sigma}$ (or increasing $R^{2}$ ) would mean more of the country's export price volatility would come from global as opposed to country-specific factors. The most complete diversification would occur when a country's exports consisted of the 'world' export bundle which would mean that the country's export price volatility would come only from systematic global factors. Over the second post-1975 period the world price series had a CV or $342 \%$ as compared with Australia's CV of 900\% (see Table 3) and so this gives some indication of the possible gains to Australia, in terms of reducing export price volatility risk, from its maximally diversifying its export base. Of course, it goes without saying that to do this may entail Australia incurring very significant 
opportunity costs of inefficiently using its scarce resources for producing in areas other than where its natural comparative advantages lie.

\section{Conclusion}

This paper distinguishes the extent to which export price variation consists of global versus country-specific risk for Australia and 13 other OECD countries. Compared to the other OECD countries, Australia's export price growth is one of the relatively more volatile in both the pre-1976 and post-1975 periods. Notwithstanding this, the results also clearly indicate that export prices in Australia during the 1976-2002 period moved more systematically with World export prices than during the pre-1976 period. During the later period, more than $56 \%$ of Australia's overall export price growth volatility could thence be attributable to global macroeconomic factors (up from $27 \%$ in the pre-1976 period). However, the other $44 \%$ of overall volatility may be regarded as country-specific volatility which, if thought desirable by policymakers, could perhaps be reduced through further diversification of the country's export base.

It also appears to be the case that in the post-1975 period Australia's Beta the response of Australian export price growth to changes in world export price growth - is not statistically different from one. In other words, whilst just a little over a half of the total variation in Australia's export price growth can be attributable to global factors $\left(R^{2}=.56\right)$, when such global fluctuations do occur, Australia's export price growth responds approximately proportionately to variations in world export price growth.

It should also be emphasised that all of the foregoing discussion naturally depends upon the choice of proxy for the "market portfolio". The IFS World Export Price series is constructed as a weighted average of the national price indices covered 
by the International Monetary Fund, the weights deriving from the importance of different countries in world trade. Its use has the advantage of being a comprehensive, ready-to-use series which is already in the public domain. An alternative approach could be to perform a Factor Analysis of the entire national export price database, extract the first factor, and use it as a proxy for the 'world' series. This type of approach has the flavour of another asset pricing model of portfolio theory, viz. the arbitrage pricing theory model (APTM). ${ }^{2}$ Such a constructed proxy would abstract from the significance of the economic influence of each included country and this may or may not be considered desirable. In any event the construction and testing of such a proxy may be worth pursuing.

Finally, it perhaps needs to be said that the paper was concerned only with export earnings risk deriving from fluctuations in prices. There is also the very important dimension of volatility in production quantities (eg., drought, in the case of rural exports) which, together with price volatility, will give rise to volatility in export revenues. Whilst this is certainly another important concern, the current paper was squarely focused only on the price dimension since, for many years, export price volatility has been - and continues to be - an issue arousing considerable policy debate in Australia.

\footnotetext{
${ }^{2}$ Harrington (1987) gives a good introduction to the APT.
} 


\section{REFERENCES}

Cashin, P. and McDermott, C.J. (2002) "Terms of Trade Shocks and the Current Account: Evidence from Five Industrial Countries", Open Economies Review 13, pp. 219-35.

Fisher, L.A . (1996) "Sources of Exchange Rate and Price Level Fluctuations in Two Commodity Exporting Countries: Australia and New Zealand", Economic Record, 72, pp.345-58.

Gruen, D. and Dwyer, J. (1996) “Are Terms of Trade Rises Inflationary?", Australian Economic Review, 114, pp.211-24.

Gruen, D. and Kortian, T. (1996) "Why Does the Australian Dollar Move So Closely with the Terms of Trade?", Reserve Bank of Australia Research Discussion Paper No. 9601, The RBA, Sydney.

Gruen, D. and Wilkinson, J. (1994) “Australia's Real Exchange Rate--Is It Explained by the Terms of Trade or by Real Interest Differentials?", Economic Record, 70, pp.204-19.

Harrington, D.R. (1987) "Modern Portfolio Theory, the CAPM and APT: A User's Guide", $2^{\text {nd }}$ Ed., Prentice-Hall, New Jersey.

Harvie, C. and Tran, V.H. (1994) "Terms of Trade Shocks and Macroeconomic Adjustment in a Resource Exporting Economy: The Case of Australia", Resources Policy, 20, pp.101-15.

Hoque, A. (1995) "Terms of Trade and Current Account Deficit in the Australian Context", Journal of Quantitative Economics, 11, pp.169-79.

International Monetary Fund (2003) International Financial Statistics, International Financial Statistics Online Service, (http://ifs.apdi.net/imf/logon.aspx), IMF, Washington, D.C.

Kent, C. (1997) "The Response of the Current Account to Terms of Trade Shocks: A Panel-Data Study", Reserve Bank of Australia Research Discussion Paper No. 9705, The RBA, Sydney.

Lintner, J. (1965) "The Valuation of Risk Assets and Selection of Risky Investments in Stock Portfolios and Capital Budgets", Review of Economics and Statistics, 47, pp.13-37.

Markowitz, H. (1959) Portfolio Selection: Efficient Diversification of Investments, Wiley, Yale University Press.

McTaggart, D. and Rogers, C. (1990) "Monetary Policy and the Terms of Trade: A Case for Monetary Base Control in Australia?", Australian Economic Review, 90, pp.38-49. 
Mossin, J. (1966) “Equilibrium in a Capital Market”, Econometrica, 34, pp.768-783.

Sharpe,W.F. (1964) "Capital Asset Prices: A Theory of Market Equilibrium

Conditions of Risk", Journal of Finance, 19, pp.425-442. 
FIGURE 1

PLOT OF ANNUAL GROWTH RATES OF EXPORT PRICES
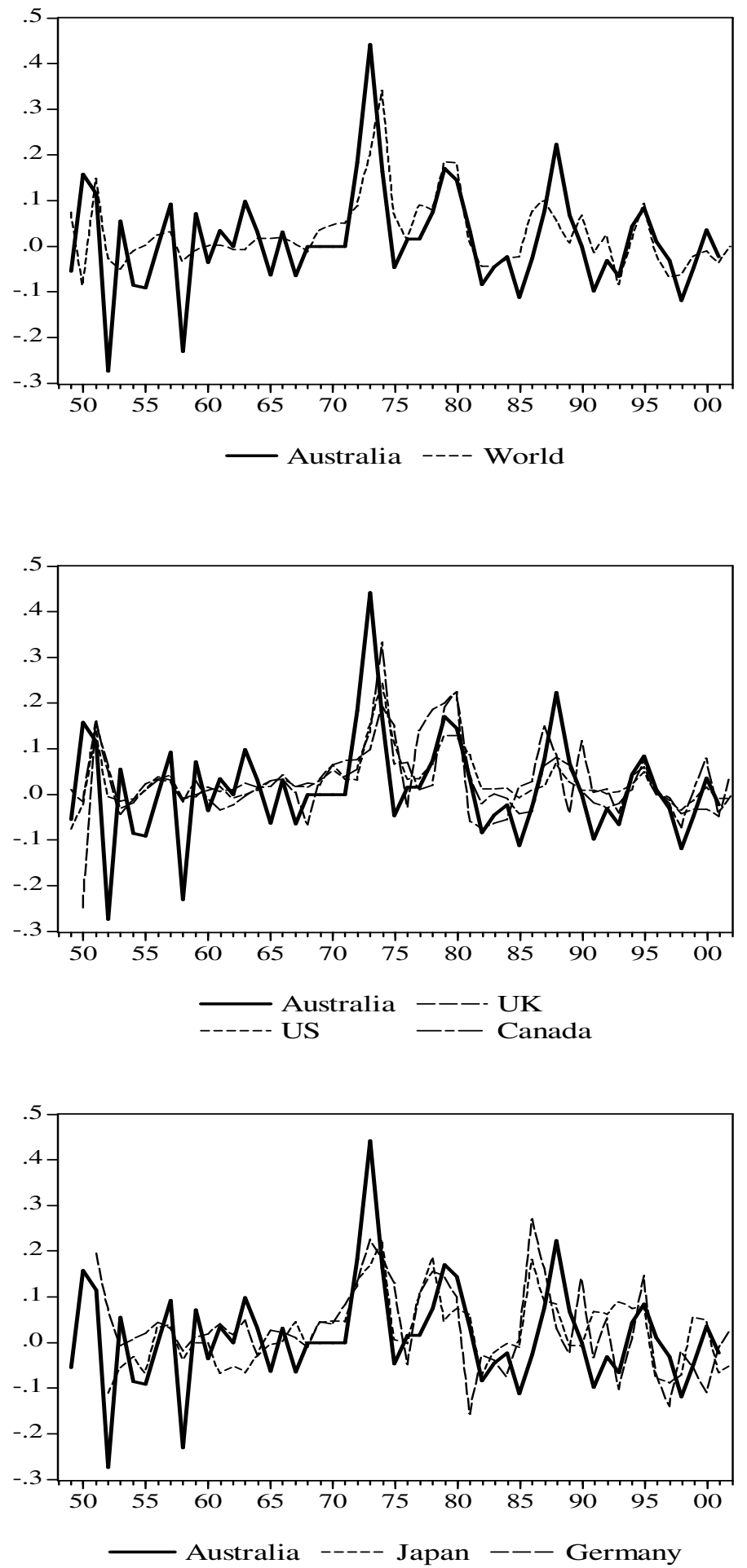

Source: International Monetary Fund (2003). 
FIGURE 2

RECURSIVE $\beta$ ESTIMATES FOR A NUMBER OF SELECTED OECD COUNTRIES

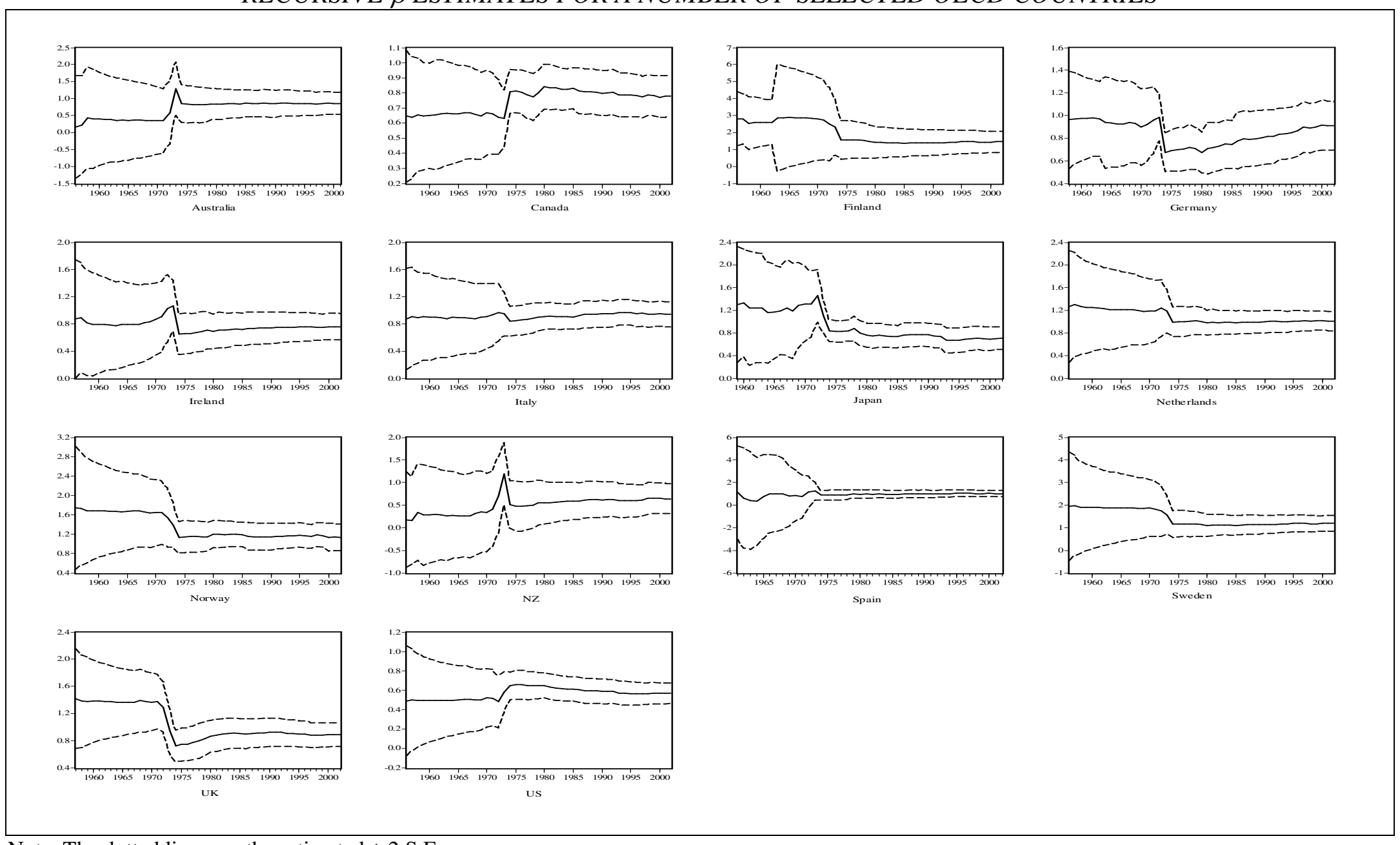

Note: The dotted lines are the estimated \pm 2 S.E. 
TABLE 1

\begin{tabular}{lccccc}
\multicolumn{1}{c}{ ESTIMATED } & $\hat{\beta}$ & \multicolumn{5}{c}{ COEFFICNTS USING } & \multicolumn{4}{c}{ ALL A VAILABLE DATA } \\
\multicolumn{1}{c}{ Country } & $\hat{\beta}^{(\mathrm{b})}$ & $t$-ratio & $R^{2}$ & $\hat{\sigma}^{(\mathrm{c})}$ & $\mathrm{DW}^{(\mathrm{d})}$ \\
\hline Australia & 0.853 & 5.3 & 0.350 & 0.090 & 2.26 \\
Canada & 0.777 & 11.6 & 0.720 & 0.038 & 1.75 \\
Finland & 1.450 & 4.7 & 0.299 & 0.173 & 1.96 \\
Germany & 0.908 & 8.4 & 0.587 & 0.059 & 1.81 \\
Ireland & 0.755 & 7.8 & 0.537 & 0.055 & 1.65 \\
Italy & 0.938 & 10.3 & 0.670 & 0.051 & 1.72 \\
Japan & 0.637 & 5.4 & 0.526 & 0.052 & 1.96 \\
Netherlands & 1.036 & 11.6 & 0.749 & 0.046 & 1.91 \\
Norway & 1.137 & 8.2 & 0.565 & 0.314 & 1.69 \\
NZ & 0.643 & 3.9 & 0.228 & 0.442 & 1.84 \\
Spain & 0.995 & 6.4 & 0.579 & 0.221 & 1.86 \\
Sweden & 1.095 & 11.3 & 0.748 & 0.059 & 1.81 \\
UK & 0.888 & 10.2 & 0.670 & 0.122 & 1.77 \\
US & 0.553 & 11.6 & 0.810 & 0.023 & 2.00
\end{tabular}

Source: International Monetary Fund (2003) on-line IFS database.

(a) Data are annual observations. The estimation period slightly varies across these countries: For Canada, Finland, Ireland, Italy, Norway and New Zealand the sample covers the 1949-2002 period; Australia (1949-2001); Germany and Sweden (19512002), Japan (1953-2002); Netherlands, the UK and the US (1950-2002), Spain (19552002). (b) $\hat{\beta}$ is the regression slope coefficient. (c) $\hat{\sigma}$ is the standard error of regression. (d) Based on the relevant critical values for $d_{U}$ and $d_{L}$, the corresponding null (of no autocorrelation) cannot be rejected at $1 \%$. 
TABLE 2

ESTIMATED $\hat{\beta}$ COEFFICIENTS FOR A NUMBER OF OECD COUNTRIES

\begin{tabular}{|c|c|c|c|c|c|c|c|c|c|c|}
\hline \multirow{2}{*}{ Countries } & \multicolumn{5}{|c|}{ Pre 1976 Period $^{(a)}$} & \multicolumn{5}{|c|}{$1976-2002$} \\
\hline & $\hat{\beta}^{(\mathrm{b})}$ & $t$-ratio & $R^{2}$ & $\hat{\sigma}^{(\mathrm{c})}$ & $\mathrm{DW}^{(\mathrm{d})}$ & $\hat{\beta}^{\text {(b) }}$ & $t$-ratio & $R^{2}$ & $\hat{\sigma}^{(\mathrm{c})}$ & $\mathrm{DW}^{(\mathrm{d})}$ \\
\hline Australia & 0.827 & 3.0 & 0.269 & 0.117 & 2.40 & 0.894 & 5.6 & 0.557 & 0.057 & $1.50^{(\mathrm{c})}$ \\
\hline Canada & 0.810 & 11.5 & 0.842 & 0.030 & 1.70 & 0.725 & 5.8 & 0.569 & 0.045 & 1.71 \\
\hline Finland & 1.571 & 2.8 & 0.241 & 0.240 & 2.01 & 1.435 & 7.1 & 0.696 & 0.063 & 1.87 \\
\hline Germany & 0.687 & 7.6 & 0.717 & 0.037 & 1.80 & 1.162 & 6.0 & 0.590 & 0.069 & 1.59 \\
\hline Ireland & 0.658 & 4.4 & 0.438 & 0.064 & 1.59 & 0.905 & 7.5 & 0.690 & 0.043 & 1.65 \\
\hline Italy & 0.849 & 7.7 & 0.703 & 0.048 & 1.53 & 1.103 & 7.6 & 0.699 & 0.052 & 1.91 \\
\hline Japan & 0.752 & 6.5 & 0.818 & 0.034 & 1.83 & 0.594 & 3.4 & 0.312 & 0.063 & 1.71 \\
\hline Netherlands & 1.026 & 7.3 & 0.713 & 0.057 & 1.78 & 1.028 & 10.5 & 0.815 & 0.035 & 1.95 \\
\hline Norway & 1.147 & 6.9 & 0.656 & 0.071 & 1.58 & 1.135 & 4.7 & 0.469 & 0.086 & 1.68 \\
\hline $\mathrm{NZ}$ & 0.477 & 1.7 & 0.108 & 0.118 & 1.77 & 0.938 & 7.0 & 0.646 & 0.052 & 1.66 \\
\hline Spain & 0.678 & 2.4 & 0.522 & 0.082 & 1.67 & 1.322 & 7.1 & 0.709 & 0.057 & 1.77 \\
\hline Sweden & 1.183 & 4.1 & 0.398 & 0.125 & 1.48 & 1.438 & 8.6 & 0.762 & 0.052 & 1.77 \\
\hline UK & 0.744 & 6.1 & 0.605 & 0.053 & 1.56 & 1.111 & 9.5 & 0.783 & 0.042 & 2.13 \\
\hline US & 0.686 & 16.5 & 0.901 & 0.021 & 1.88 & 0.330 & 4.2 & 0.660 & 0.024 & 1.72 \\
\hline
\end{tabular}

Source: International Monetary Fund (2003) on-line IFS database.

(a) Data are annual observations. The estimation period varied slightly across the countries: For Canada,

Finland, Ireland, Italy, Norway, Australia, and New Zealand the sample covers the 1949-1975 period;

Germany and Sweden (1951-1975), Japan (1953-1975); Netherlands, the UK and the US (1950-1975), Spain (1955-1975). (b) $\hat{\beta}$ is the regression slope coefficient. (c) $\hat{\sigma}$ is the standard error of regression. (d) Based on the relevant critical values for $d_{U}$ and $d_{L}$, the corresponding null (of no autocorrelation) cannot be rejected at $1 \%$. 
TABLE 3

VOLATILITY STATISTICS OF THE GROWTH OF EXPORT UNIT PRICES FOR SELECTED OECD COUNTRIES

\begin{tabular}{|c|c|c|c|c|c|c|c|c|c|c|c|c|c|c|c|c|}
\hline \multirow{2}{*}{ Countries } & \multicolumn{8}{|c|}{ Pre-1976 Period } & \multicolumn{8}{|c|}{ Post-1975 Period } \\
\hline & Mean & SD & $\mathrm{CV} \%$ & $\begin{array}{c}\text { SD } \\
\text { Rank }\end{array}$ & $\begin{array}{c}\text { CV } \\
\text { Rank }\end{array}$ & $\begin{array}{c}\hat{\sigma} \\
\text { Rank }\end{array}$ & $\begin{array}{c}\hat{\beta} \\
\text { Rank }\end{array}$ & $\begin{array}{c}R^{2} \\
\text { Rank }\end{array}$ & Mean & $\mathrm{SD}$ & $\begin{array}{c}\mathrm{CV} \\
\%\end{array}$ & $\begin{array}{c}\text { SD } \\
\text { Rank }\end{array}$ & $\begin{array}{c}\text { CV } \\
\text { Rank }\end{array}$ & $\begin{array}{c}\hat{\sigma} \\
\text { Rank }\end{array}$ & $\begin{array}{c}\hat{\beta} \\
\text { Rank }\end{array}$ & $\begin{array}{c}R^{2} \\
\text { Rank }\end{array}$ \\
\hline Australia & 0.020 & 0.135 & 683 & 13 & 11 & 11 & 9 & 3 & 0.009 & 0.084 & 900 & 8 & 14 & 9 & 4 & 3 \\
\hline Canada & 0.037 & 0.075 & 200 & 3 & 2 & 2 & 8 & 13 & 0.024 & 0.067 & 285 & 2 & 3 & 5 & 3 & 4 \\
\hline Finland & 0.030 & 0.270 & 905 & 15 & 14 & 14 & 14 & 2 & 0.010 & 0.110 & 1070 & 14 & 15 & 11 & 13 & 9 \\
\hline Germany & 0.054 & 0.068 & 127 & 2 & 1 & 4 & 5 & 11 & 0.016 & 0.106 & 657 & 13 & 11 & 13 & 11 & 5 \\
\hline Ireland & 0.027 & 0.084 & 309 & 6 & 6 & 8 & 2 & 5 & 0.022 & 0.076 & 349 & 5 & 8 & 4 & 5 & 8 \\
\hline Italy & 0.016 & 0.086 & 546 & 8 & 9 & 5 & 10 & 9 & 0.027 & 0.092 & 342 & 10 & 6 & 8 & 8 & 10 \\
\hline Japan & 0.011 & 0.078 & 728 & 4 & 12 & 3 & 7 & 12 & 0.03 & 0.074 & 247 & 4 & 2 & 12 & 2 & 1 \\
\hline Netherlands & 0.022 & 0.102 & 463 & 9 & 8 & 7 & 11 & 10 & 0.018 & 0.080 & 448 & 6 & 9 & 2 & 7 & 14 \\
\hline Norway & 0.029 & 0.119 & 416 & 11 & 7 & 9 & 12 & 8 & 0.02 & 0.116 & 581 & 15 & 10 & 14 & 10 & 2 \\
\hline NZ & 0.020 & 0.123 & 606 & 12 & 10 & 12 & 1 & 1 & 0.025 & 0.083 & 327 & 7 & 5 & 6 & 6 & 6 \\
\hline Spain & 0.009 & 0.110 & 1191 & 10 & 15 & 10 & 3 & 6 & 0.014 & 0.102 & 754 & 12 & 13 & 10 & 12 & 11 \\
\hline Sweden & 0.019 & 0.158 & 837 & 14 & 13 & 13 & 13 & 4 & 0.014 & 0.102 & 752 & 11 & 12 & 7 & 14 & 12 \\
\hline UK & 0.029 & 0.082 & 284 & 5 & 5 & 6 & 6 & 7 & 0.029 & 0.088 & 304 & 9 & 4 & 3 & 9 & 13 \\
\hline US & 0.032 & 0.064 & 201 & 1 & 3 & 1 & 4 & 14 & 0.025 & 0.040 & 163 & 1 & 1 & 1 & 1 & 7 \\
\hline World & 0.035 & 0.084 & 244 & 7 & 4 & & & & 0.020 & 0.070 & 342 & 3 & 7 & & & \\
\hline
\end{tabular}

Sources: (1) International Monetary Fund (2003) on-line IFS database. (2) the authors' calculations.

Notes: A higher rank means that the corresponding statistic for the country in question is higher compared with the other countries in the set (rank goes from 1 to 15$)$. $\mathrm{SD}=$ standard deviation and $\mathrm{CV}=$ coefficient of variation. 
TABLE 4

TESTING THE NULL OF $\beta=1$

\begin{tabular}{lcccccc}
\hline \multirow{2}{*}{ Countries } & \multicolumn{3}{c}{ Pre-1976 period } & \multicolumn{3}{c}{ Post-1975 period } \\
\cline { 2 - 7 } & $\hat{\beta}$ & $\mathrm{F}$ statistic & $\mathrm{p}$-value & $\hat{\beta}$ & $\mathrm{F}$ statistic & P-value \\
\hline Australia & 0.827 & $\mathrm{~F}(1,25)=0.40$ & $\mathbf{0 . 5 3}$ & 0.894 & $\mathrm{~F}(1,25)=0.44$ & $\mathbf{0 . 5 1}$ \\
Canada & 0.810 & $\mathrm{~F}(1,25)=7.30$ & 0.01 & 0.725 & $\mathrm{~F}(1,25)=4.76$ & 0.04 \\
Finland & 1.571 & $\mathrm{~F}(1,25)=1.05$ & $\mathbf{0 . 3 2}$ & 1.435 & $\mathrm{~F}(1,24)=4.63$ & 0.04 \\
Germany & 0.687 & $\mathrm{~F}(1,25)=1.05$ & $\mathbf{0 . 3 2}$ & 1.162 & $\mathrm{~F}(1,25)=0.70$ & $\mathbf{0 . 4 1}$ \\
Ireland & 0.658 & $\mathrm{~F}(1,25)=5.28$ & 0.03 & 0.905 & $\mathrm{~F}(1,25)=0.61$ & $\mathbf{0 . 4 4}$ \\
Italy & 0.849 & $\mathrm{~F}(1,25)=1.86$ & $\mathbf{0 . 1 8}$ & 1.103 & $\mathrm{~F}(1,25)=0.50$ & $\mathbf{0 . 4 8}$ \\
Japan & 0.752 & $\mathrm{~F}(1,20)=4.55$ & 0.05 & 0.594 & $\mathrm{~F}(1,25)=5.27$ & 0.03 \\
Netherlands & 1.026 & $\mathrm{~F}(1,24)=0.03$ & $\mathbf{0 . 8 6}$ & 1.028 & $\mathrm{~F}(1,25)=0.08$ & $\mathbf{0 . 7 7}$ \\
Norway & 1.147 & $\mathrm{~F}(1,25)=0.78$ & $\mathbf{0 . 3 9}$ & 1.135 & $\mathrm{~F}(1,25)=0.31$ & $\mathbf{0 . 5 8}$ \\
NZ & 0.477 & $\mathrm{~F}(1,25)=3.62$ & 0.07 & 0.938 & $\mathrm{~F}(1,24)=0.21$ & $\mathbf{0 . 6 5}$ \\
Spain & 0.678 & $\mathrm{~F}(1,18)=1.35$ & $\mathbf{0 . 2 6}$ & 1.322 & $\mathrm{~F}(1,24)=3.00$ & $\mathbf{0 . 1 0}$ \\
Sweden & 1.183 & $\mathrm{~F}(1,25)=0.39$ & $\mathbf{0 . 5 4}$ & 1.438 & $\mathrm{~F}(1,24)=6.83$ & 0.02 \\
UK & 0.744 & $\mathrm{~F}(1,24)=4.35$ & 0.05 & 1.111 & $\mathrm{~F}(1,25)=0.90$ & $\mathbf{0 . 3 5}$ \\
US & 0.686 & $\mathrm{~F}(1,24)=57.57$ & 0.00 & 0.330 & $\mathrm{~F}(1,24)=71.85$ & 0.00 \\
\hline
\end{tabular}

